\title{
Controls on Barite Mineralization in a Major Intracontinental Shear Zone: Carboniferous of the Cobequid Highlands, Nova Scotia
}

\author{
Georgia Pe-Piper 1,*(D) and David J. W. Piper ${ }^{2,3}$ \\ 1 Department of Geology, Saint Mary's University, Halifax, NS B3H 3C3, Canada \\ 2 Natural Resources Canada, Geological Survey of Canada Atlantic, Bedford Institute of Oceanography, \\ Dartmouth, NS B2Y 4A2, Canada; david.piper@canada.ca \\ 3 Department of Oceanography, Dalhousie University, Halifax, NS B3H 4R2, Canada \\ * Correspondence: gpiper@smu.ca
}

Citation: Pe-Piper, G.; Piper, D.J.W. Controls on Barite Mineralization in a Major Intracontinental Shear Zone: Carboniferous of the Cobequid Highlands, Nova Scotia. Minerals 2021, 11, 1413. https://doi.org/ $10.3390 / \min 11121413$

Academic Editor: Ricardo Ferreira Louro Silva

Received: 29 November 2021 Accepted: 13 December 2021 Published: 14 December 2021

Publisher's Note: MDPI stays neutral with regard to jurisdictional claims in published maps and institutional affiliations.

Copyright: (c) 2021 by the authors. Licensee MDPI, Basel, Switzerland. This article is an open access article distributed under the terms and conditions of the Creative Commons Attribution (CC BY) license (https:// creativecommons.org/licenses/by/ $4.0 /)$.

\begin{abstract}
Prominent veins of late Carboniferous barite, associated with fluorite and calcite, outcrop close to older granite plutons along an intracontinental shear zone that was active throughout the Carboniferous in southeastern Canada. Some barite is stratigraphically constrained to younger than $315 \mathrm{Ma}$ and final mineralization is constrained by a published $\mathrm{Rb}-\mathrm{Sr}$ isochron of $300 \pm 6 \mathrm{Ma}$. Barite occurrences in the Carboniferous basins of central Nova Scotia, $50 \mathrm{~km}$ to the south, are synchronous with or post-date ankerite-siderite-magnetite-pyrolusite and $\mathrm{Pb}-\mathrm{Zn}$ mineralization, which was facilitated by fluid interaction with thick evaporites. This study aims to determine controls on the distribution of barite in the shear zone, from field relationships, vein petrography and isotope geochemistry of minerals. The isotope chemistry of shear zone barite is similar to that occurring in $\mathrm{Pb}-\mathrm{Zn}-\mathrm{Mn}-\mathrm{Ba}$ mineralization to the south, suggesting a common origin. Veins of barite, associated with fluorite, represent the youngest and regionally coolest phase of a $70 \mathrm{Ma}$ history of Carboniferous mineralized veins along the Minas Fault Zone. Their prominence close to granite plutons reflects brittle deformation of the deeply-rooted granites in a complexly deforming fault zone, but the origin of abundant $\mathrm{F}$ remains uncertain.
\end{abstract}

Keywords: barite; veins; isotope chemistry; petrography

\section{Introduction}

Barite commonly occurs in faults and fractures in Lower Carboniferous sedimentary rocks close to the continental-scale Cobequid Shear Zone and the later Minas Fault Zone along the southern margin of the Cobequid Highlands of northern Nova Scotia (Figure 1) [1-4]. In many cases, the barite occurs together with specularite, other iron minerals (e.g., goethite, ankerite, siderite, and pyrite), or fluorite and less commonly with chalcopyrite, sphalerite, galena or manganese minerals. This complex fault system was initiated in the Late Devonian following collision of the outboard peri-Gondwanan Appalachian terranes with Laurentia [5], with the local component of the fault system known as the Cobequid Shear Zone, with dextral slip on ENE-trending faults. The western part of this shear zone was reactivated with continuing dextral slip as part of the E-W Minas Fault Zone in the late Carboniferous, during the final Gondwana-Laurentia collision that resulted in the formation of Pangea [6]. These fault systems continued into the USA in the southwest and into Europe in the east. Deformation along these faults extended at least from 370 to $300 \mathrm{Ma}$ and localised a complex succession of vein minerals [6], including important iron deposits interpreted as part of an iron-oxide-copper-gold (IOGC) mineralizing system [4]. The barite mineralization appears to be late in this succession of mineral types [6]. 


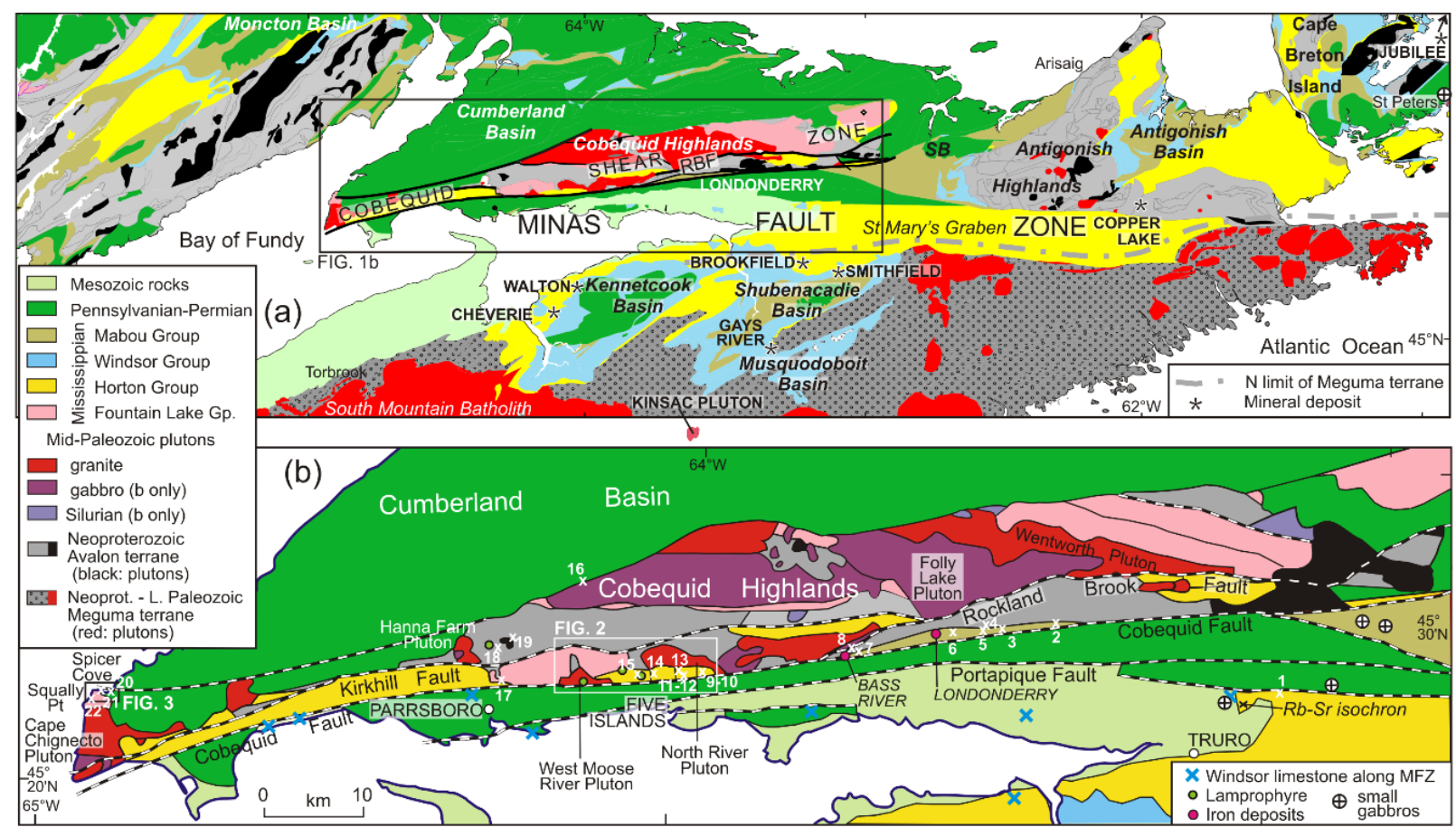

Figure 1. (a) Geological map of the Minas Fault Zone in northern Nova Scotia (modified from [4]) and (b) more detailed map of the Cobequid Highlands showing location of barite mineralization (numbers refer to Table 1; modified from [6]).

The general style of this mineralization is similar to the barite-lead-zinc mineralization of the Carboniferous basins of central Nova Scotia (Figure 1a), including the former Walton barite mine and the active Gays River lead-zinc mine [7]. These deposits are generally carbonate hosted sulfide deposits with minor liquid petroleum. The barite veins are clearly epigenetic and structurally controlled. On the other hand, the distribution of barite mapped by [2,3] in the Cobequid Highlands shows a close spatial association with granite and/or gabbro plutons close to the Cobequid Fault (Figure 1b). Barite deposits are notably absent, for example, east of the Wentworth pluton or between the Cape Chignecto and Hanna Farm plutons. This raises the question as to whether the mineralization and alteration of country rock is genetically associated with early Carboniferous igneous activity in the Cobequid Highlands [8] or whether it is part of the ca. 300 Ma metallogeny of the Carboniferous basins of central Nova Scotia [7,9].

We have studied this problem by detailed examination of barite in two general areas. (1) At Five Islands, barite veins in the Lower Carboniferous Horton Group sandstones and shales are found close to the North River granite pluton, and the Horton Group itself is cut by hypabyssal porphyritic rhyolite. (2) In the northern Chignecto Peninsula, barite veins are geographically remote from the mineralization of the Carboniferous basins of central Nova Scotia, and are close to the Cape Chignecto granite pluton emplaced in the latest Devonian to earliest Carboniferous [6].

\section{Regional Geological Setting and Previous Studies of Barite Distribution}

The Cobequid Highlands (Figure 1b) form a horst with Neoproterozoic crystalline basement of the Avalon terrane, as summarized by [6]. In the study area, the volcanogenic Jeffers Group is intruded by diorite-granodiorite plutons. The late Devonian to early Carboniferous Cobequid Shear Zone formed part of a NE-SW-trending, crustal-scale, orogen-parallel shear system, with some $300 \mathrm{~km}$ dextral displacement, extending from the southern Appalachians to the Caledonides of Scotland [5]. Granite and gabbro plutons, together with coeval flood basalts, were emplaced between 370 and $355 \mathrm{Ma}$ and progressively deformed in this shear system. The plutons have a general A-type geochemical character with trace elements characteristic of within-plate granites. In the early Carbonif- 
erous, the Kirkhill and Rockland Brook faults (Figure 1b) formed the abrupt northern edge of the Kennetcook Basin half-graben (Figure 1a). This basin, and the Shubenacadie and Musquodoboit basins to the south in central Nova Scotia, accumulated several kilometres of terrestrial, lacustrine and marine sandstone, shale, limestone, gypsum and salt, assigned to the Horton, Windsor and Mabou groups. In the late Carboniferous to Permian, the collision of Africa with Laurentia in the southern Appalachians resulted in the Alleghanian orogenic phase. In the northern Appalachians, much of this deformation was taken up along the E-W-trending Minas Fault Zone [4]. Parts of the Minas Fault Zone reactivated older faults within the Cobequid Shear Zone. Late Carboniferous mineralization along the Minas Fault Zone includes large iron ore deposits, base metal sulfides, barite and REE minerals [4]. Thick fluvial deposits of the Cumberland and Pictou groups accumulated to the north and south of the Cobequid Highland horst.

In Nova Scotia generally, six styles of barite mineralization were recognised in the classic review of Felderhof [1]. Type A occupies faults and fractures in unaltered country rock, and is commonly associated with fluorite and celestite. All the occurrences from the Cobequid Highlands considered in this paper (Table 1) are type-A deposits, except for the Bass River mine deposit (11 in Table 1), which is a stratigraphically controlled replacement mineral deposit designated as type B [1].

Table 1. Barite deposits in the Cobequid Highlands and location of samples analysed in this study.

\begin{tabular}{|c|c|c|c|c|c|c|}
\hline No & UTM North & UTM East & Location & Minerals & Analysed Samples & References \\
\hline 1 & $5,029,120$ & 487,260 & East Mountain & pyrol, mang, psilom, brt & & [3] \\
\hline 2 & $5,038,175$ & 462,865 & Totten Brook & hem, lm, ank, brt & & [3] \\
\hline 3 & $5,036,110$ & 452,470 & Londonderry & brt, sd, ank & & [3] \\
\hline 4 & $5,037,390$ & 451,290 & Londonderry & $\begin{array}{c}\text { hem, lm, gt, sd, ank, py, mrc, } \\
\text { mag, brt }\end{array}$ & & {$[1-3]$} \\
\hline 5 & $5,036,685$ & 451,315 & Londonderry & ank, sd, gt, lm, spec, brt & & [2] \\
\hline 6 & $5,036,320$ & 448,535 & Londonderry & brt, ank, sd, gt, lm, spec & & [2] \\
\hline 7 & $5,034,550$ & 439,510 & Bass River (mine) & brt & & {$[1,2]$} \\
\hline 8 & $5,034,750$ & 439,255 & Bass River falls & mag, py, brt & & [3] \\
\hline 9 & $5,032,235$ & 420,765 & East River & $\begin{array}{l}\text { brt, spec, ccp, fl, py, cal, } \\
\text { chl, qtz }\end{array}$ & $8015,8016,8018$ & {$[1,3]$} \\
\hline 10 & $5,033,055$ & 421,285 & East River & brt, spec, fl, py, cal, chl, qtz & $7791,8023,8025,8026$ & {$[1,3]$} \\
\hline 11 & $5,032,375$ & 418,530 & $\begin{array}{l}\text { Bass River of Five } \\
\text { Is (mine) }\end{array}$ & brt, spec, ccp, fl & $8069,8071,8079$ & [1-3] \\
\hline 12 & $5,032,125$ & 418,320 & Bass River of Five Is & brt, fl & & [2] \\
\hline 13 & $5,033,320$ & 416,780 & Vault Brook & brt & & [3] \\
\hline 14 & $5,032,090$ & 414,515 & Lynn Road & $\mathrm{ccp}, \mathrm{gn}, \mathrm{brt}, \mathrm{fl}$ & & [2] \\
\hline 15 & $5,031,755$ & 412,710 & Lynn Road & brt, fl, spec, ank, cal & 8032,8054 & {$[2,3]$} \\
\hline 16 & $5,031,570$ & 398,510 & Gavin Brook & brt, gn, ccp, sp & & [1] \\
\hline 17 & $5,045,940$ & 407,470 & South Brook & brt & & [1] \\
\hline 18 & $5,035,100$ & 397,450 & Jeffers Brook & gn, ccp, sp, brt & & [3] \\
\hline 19 & $5,036,485$ & 398,965 & Jeffers Brook & gn, ccp, sp, brt & & [3] \\
\hline 20 & $5,032,373$ & 351,636 & Spicer Cove & brt & & [1] \\
\hline 21 & $5,032,414$ & 350,705 & Squally Point & brt, fl & 5003 & [1] \\
\hline 22 & $5,032,075$ & 350,262 & Andersons Cove & brt & & [10] \\
\hline
\end{tabular}

Mineral abbreviations follow Whitney and Evans [11] and pyrol = pyrolusite, mang = manganite, and psilom = psilomelane; minerals given in approximate order of abundance.

Along the Cobequid Shear Zone and Minas Fault Zone in the study area, complex veins including albite, quartz, chlorite, siderite, ankerite and magnetite are widespread. Their paragenetic sequence and age have been determined, ranging from at least 355 to $320 \mathrm{Ma}$ [6]. No discrete barite veins were investigated, but at least half of the samples examined in that study contained trace amounts of barite (Supplementary Table S1). Modes of occurrence of this minor barite included (1) as patches or filling voids in minerals such as quartz, albite, calcite, and a $\mathrm{TiO}_{2}$ mineral (likely rutile) referred to subsequently as titania; (2) at the rims of open fractures; (3) in calcite veins; (4) associated with limonite and $\mathrm{Mn}-\mathrm{Mg}$ siderite; (5) associated with galena, pyrite and limonite in open fractures. All these modes of occurrence suggest that barite mineralization was late. 
In central Nova Scotia, commercially important barite deposits are found at Walton and Brookfield [7,9] (Figure 1a). The Walton Ba-Pb-Zn-Cu-Ag deposit includes barite and sulfide ore bodies in lower Windsor Group limestone, with barite synchronous with and post-dating sulfides. A similar paragenesis is found at the smaller Smithfield deposit. The Brookfield barite deposit occupies a fault zone in the Horton Group and was synchronous with and post-dates siderite. Additionally of note is the Gays River $\mathrm{Zn}-\mathrm{Pb}$ sulfide deposit which contained 12 million metric tons of 7\% combined lead and zinc hosted in a dolomitized carbonate bank of the basal Windsor Group. In the region, barite veins also occur in Windsor Group limestones and in granite of the Kinsac pluton [1,7]. In the Minas Fault Zone, Horton Group shales at Upper Brookside yielded a $\mathrm{Rb}-\mathrm{Sr}$ isochron age of $300 \pm 6 \mathrm{Ma}$, interpreted as the last time that there was flow of hydrothermal fluids with Sr [7]. In the literature, this age has been widely applied to the sulfide mineralization in central Nova Scotia.

\section{Materials and Methods}

Field mapping and sampling were carried out, principally in brooks and coastal cliffs. Bedrock in other areas is obscured by glacial till. Polished thin sections were examined by scanning electron microscope and minerals were analysed by energy dispersive spectroscopy (EDS) in the same manner as [12]. A set of 24 host rock samples (Supplementary Table S2) were analysed for 10 major and minor element oxides and 14 trace elements on a Philips PW 1400 sequential X-ray fluorescence spectrometer using a Rh-anode X-ray tube at Saint Mary's University. The major element analyses were made on fused beads prepared from ignited samples, whereas the trace element analyses were made on pressed powder pellets. Analytical precision, as determined from replicate analyses, is generally better than $2 \%$, except for $\mathrm{MgO}, \mathrm{Na}_{2} \mathrm{O}$ and $\mathrm{Nb}$ which are better than $5 \%$ and Th which is better than $10 \%$. Some barite samples were analysed in the same way. Strontium isotopes in barite, fluorite and calcite were analysed by Geospec Consultants Ltd., Edmonton, AB, Canada, in a Micromass (Manchester, UK) VG354 mass spectrometer using a five collector peak hopping technique. Oxygen and sulfur isotopes were determined on barite samples by Actlabs Ltd. (Ancaster, ON, Canada) [13]. Lead isotopes were determine by Geospec Consultants Ltd. using procedures summarized by [8].

\section{Results}

\subsection{Field Observations}

In the Five Islands area, the major barite occurrence in the East River section (10 in Table 1, Figure 2) occurs in fine-grained sandstones and dark gray and black siltstones of the basal Carboniferous Horton Group, and the mineralization is hosted within common lenticular barite veins that pinch and swell forming pods of barite. A typical vein is approximately $10 \mathrm{~cm} \times 30 \mathrm{~cm}$ in size; however, there are rare pods ranging up to $100 \mathrm{~cm}$ in length. The mineralization infilling these veins consists predominantly (95\%) of coarse, tabular, pinkish-white and white barite, with well-formed euhedral crystals of purplishbrown calcite along the margins. A $1 \mathrm{~m}$ in width breccia zone located in this area is also partially cemented with medium-grained, tabular, white barite. There is no wall-rock alteration apparent in hand samples associated with the mineralization.

Barite mineralization in the Bass River of Five Islands (Figure 2) is found at the site of the abandoned Eureka barite mine (11 in Table 1), worked between 1866 and 1876 [1], and $200 \mathrm{~m}$ farther downstream (12 in Table 1). The host rock is thinly-bedded, gray silty argillite and siltstone, with interbedded fine- to medium-grained gray sandstone. Several fault zones in the area are filled with fault gouge containing cataclastic country rock, locally cemented with calcite. Hand specimens show wall-rock alteration. The country rock in Bass River is less deformed than that of the East River; however, bedding orientations are similar, generally striking east-west and dipping between $40^{\circ}$ and $70^{\circ} \mathrm{S}$. Faults, vein, fractures, and breccia zones cross cut bedding, and most trend east-west dipping at $30^{\circ}$ to $70^{\circ}$. They are cut by rare younger northwest- to southeast-trending shears and calcite 
veins dipping $50-75^{\circ}$. Near the Eureka mine, the country rock is cut by several irregular barite veins of $1-2 \mathrm{~cm}$ in length with no visible calcite. Barite also cements breccia zones up to $30 \mathrm{~cm}$ in width and forms lenticular veins. The veins contain pinkish-white, coarse, tabular, barite, whereas the barite in the breccia zones is more massive (95\%) and occurs with calcite $(4 \%)$ and rare fluorite $(1 \%)$ that is purple, colourless, or amber.

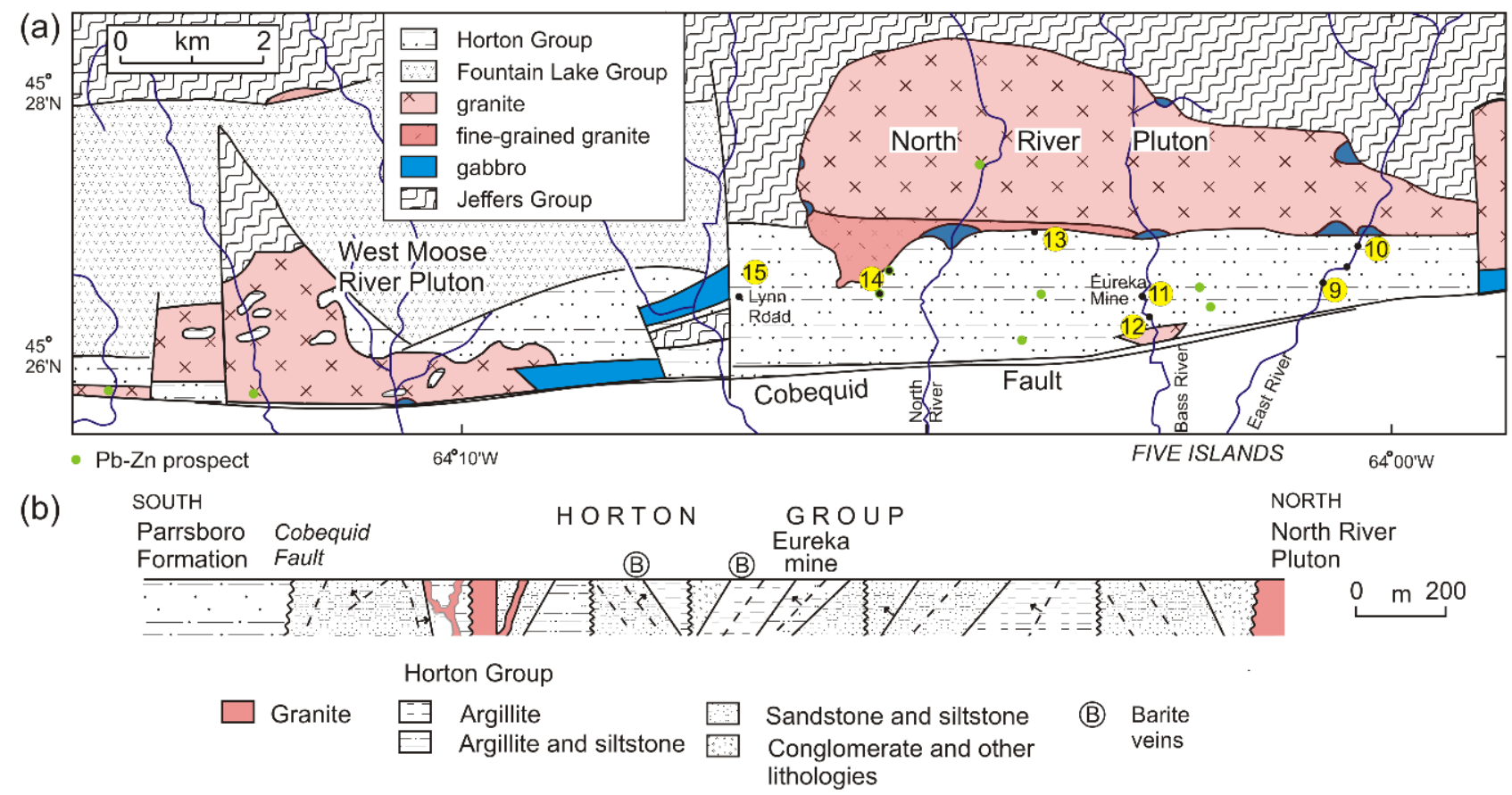

Figure 2. (a) Geological map of the area north of Five Islands and (b) cross section down the Bass River, showing location of barite mineralization (numbers refer to Table 1). $\mathrm{Pb}-\mathrm{Zn}$ mineralization from [3] also shown. Base map modified from [14].

Barite was only found in one locality along the numerous road-cut exposures on the west side of Lynn Road (15 in Table 1, Figure 2), where it is hosted by grey siltstones and argillites. Barite is found filling small ( $1 \mathrm{~cm}$ or less) irregular and lenticular fractures, generally associated with calcite. The barite is generally more massive than that found further to the east, but is still occasionally found as medium- to coarse-grained, tabular, pinkish-white crystals. The veins consist primarily of massive orange-pink calcite (80\%) with minor barite $(20 \%)$, and the two minerals often appear to be intermixed.

North of the Cape Chignecto granite pluton (Figure 1b), three barite localities are known. In Andersons Cove (Figure 3), steeply dipping barite (70\%) and calcite (30\%) veins cut a highly sheared diabase dyke that cuts flow-banded rhyolite of the Fountain Lake Group. A little to the north, steeply-dipping barite veins cut hyaloclastites of the Fountain Lake Group. A series of subvertical barite $(90 \%)$ and fluorite $(10 \%)$ veins cut Fountain Lake Group rhyolite east of Squally Point (21 in Table 1) and may be a continuation of the veins in Andersons Cove. The fluorite occurs in the outer part of the veins and the barite in the centre. Wider barite veins (with some calcite, $10 \%$ ) outcrop on the foreshore of Spicer Cove along the fault contact between the Bashkirian (Duckmantian) Ragged Reef Formation [15,16], and Tournaisian Falls Formation conglomerate (Figure 3).

\subsection{Alteration of Country Rock}

Twelve samples from Horton Group argillite and sandstone forming the host rocks of the barite veins in the Five Islands area have been studied in detail using BSE images and EDS analyses of mineral chemistry (Figures 4 and 5; Supplementary Figure S1). Detrital minerals seen in these rocks include: quartz, K-feldspars, albite, muscovite, clays, and apatite. Bedding-parallel diagenetic pyrite and chlorite are common in argillite. Fine- 
grained sandstones have laminae rich in detrital muscovite that is partially altered to chlorite (Figure 4A). In addition, one rhyolite from the Squally Point has been analysed (Figure 5A,B).

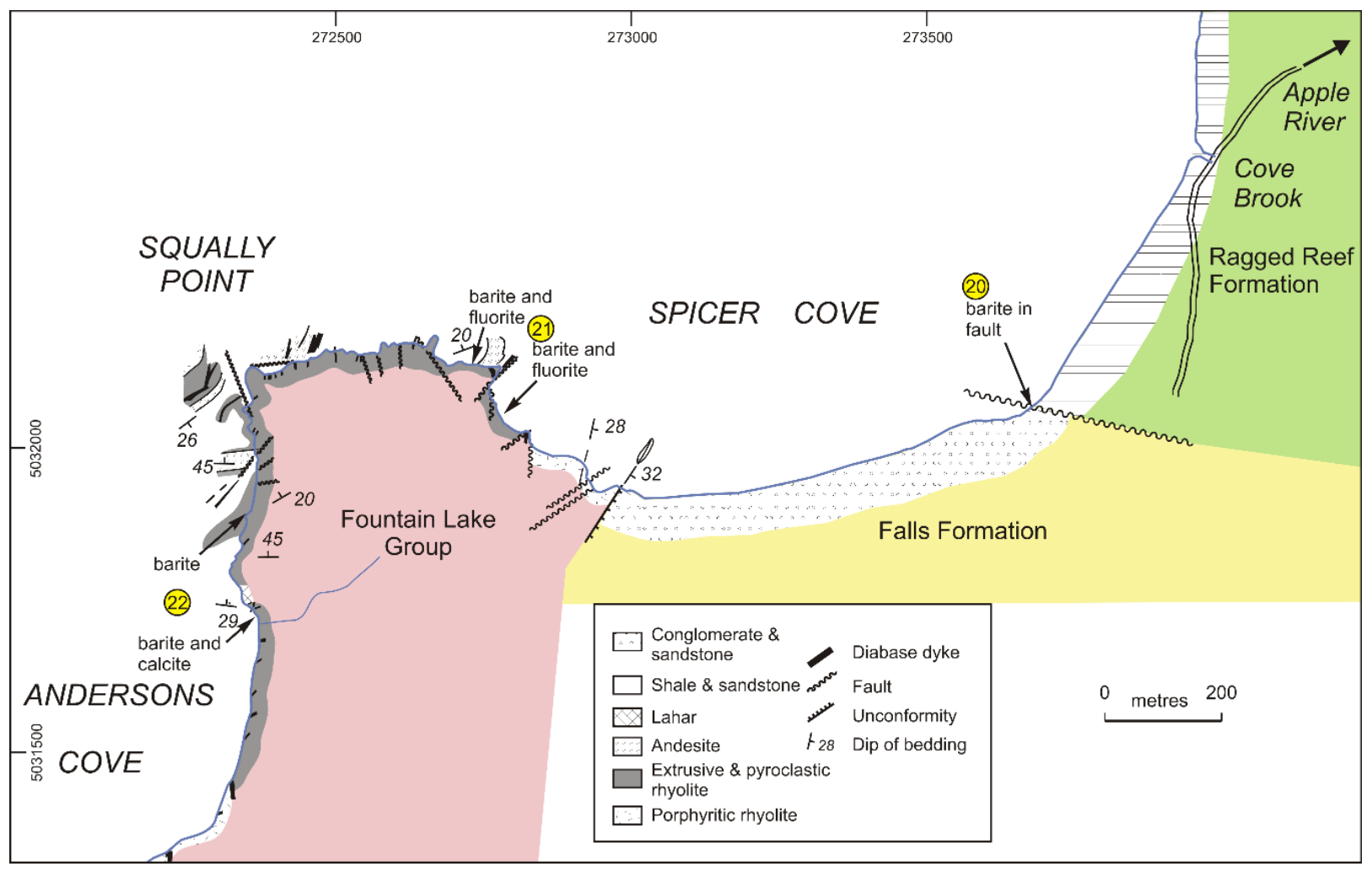

Figure 3. Geological map of the Squally Point area (UTM coordinates), showing location of barite mineralization (numbers refer to Table 1). Base map modified from [10]. Lithologies of coastal outcrops in legend; colours indicate stratigraphic units.

At first sight, the barite veins cut altered country rock. However, there is no direct evidence that any of the macroscopic alteration in the country rock is related to the barite veins. Argillite and sandstone are in places cut by composite veins that predate the barite, with later minerals filling the centre of a widening vein, or filling intergranular voids that opened up during renewed deformation. The most common veins (Figure $4 \mathrm{~B}$ ) have an outer rim of quartz $+\mathrm{Mg}$-chlorite, passing towards the centre of the vein first to predominant $\mathrm{Mg}$-chlorite, then calcite, and finally to a central zone with Fe-chlorite, ankerite, pyrite and quartz (Figure 4A,B; Supplementary Table S3). In places, internal deformation of veins (red circle in Figure 4B) created space for precipitation of minerals characteristic of the central zone such as Fe-chlorite and ankerite altered to limonite (Figure 4D). This deformation appears to post-date the precipitation of calcite.

Almost all of the thin sections of unaltered argillite host tiny 1-3 mm fracture infills or small tension gashes, generally filled with quartz and/or calcite. The altered argillites exhibit either partial calcite replacement of the clays and feldspars or an alteration halo of chlorite around veins and tension gashes. Two slides (7781B and 8053B) also contain scattered minor blebs of chalcopyrite within the host. Pyrite is common: some is clearly post-compaction but some is clearly early diagenetic.

Alteration in sandstones is visible as calcite replacement of plagioclase, interstitial chlorite growths, and muscovite and minor biotite growths in interstitial openings. Many samples host traces to approximately $2 \%$ small hematite crystals throughout the groundmass. Sample 8015 contains common late biotite (Figure 5C) that fills porosity between quartz grains, but may have nucleated on original detrital biotite grains. The biotite is $\mathrm{Mg}$ rich with $\mathrm{TiO}_{2}<1 \mathrm{wt} . \%$ (Supplementary Table S4) and is similar to secondary biotite in the 
nearby West Moose River Pluton [17]. Similar biotite, but in much smaller quantity, is seen in other altered sandstone samples.
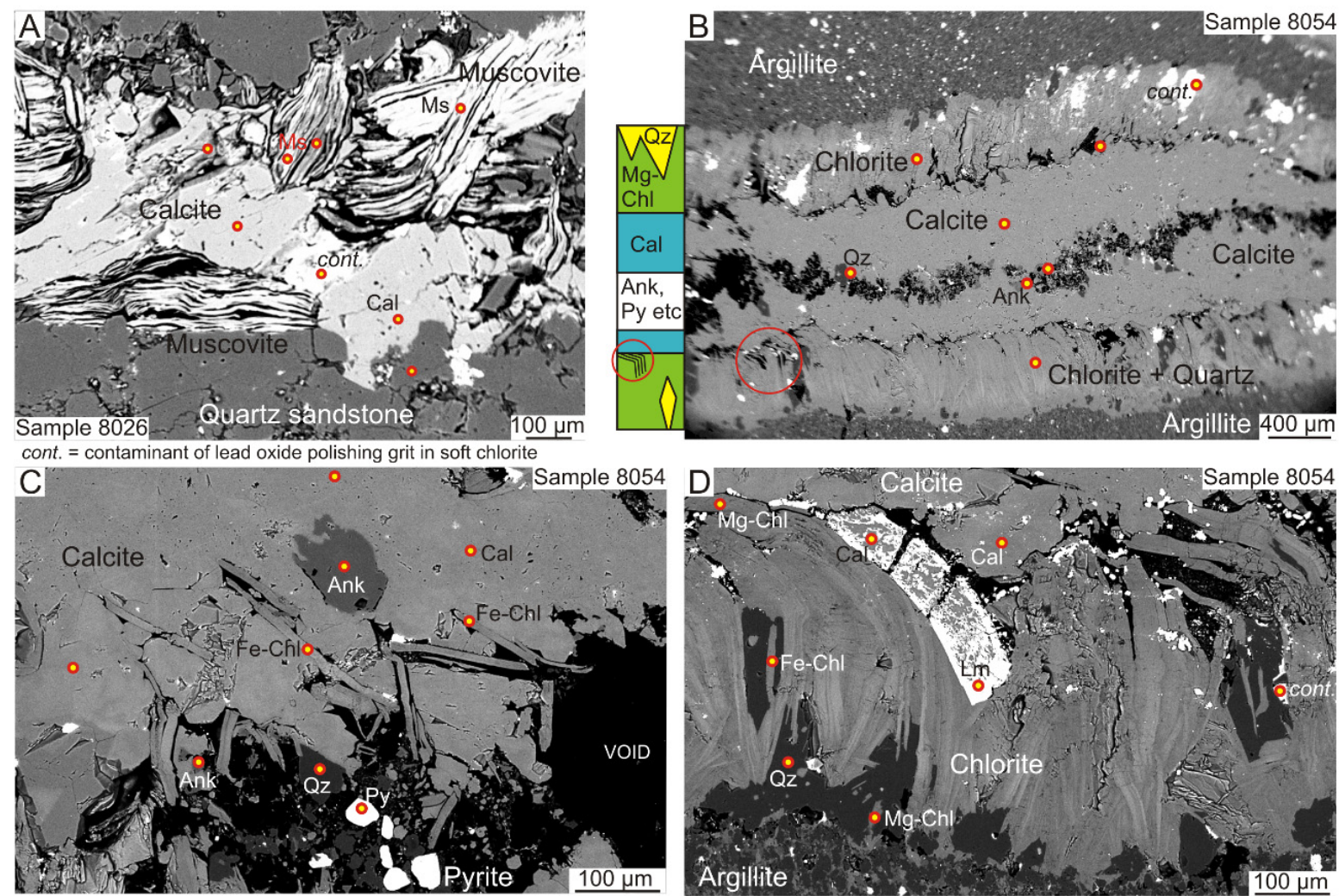

- position of EDS analysis (Supplementary Figure S1)

Figure 4. Backscattered electron images of veins in argillite and sandstone, Five Islands area. cont. = contaminant from polishing process. (A) Micaceous lamina in quartz sandstone cut by irregular calcite vein. (B) Composite quartz-chloritecalcite vein with central zone of ankerite, pyrite, Fe-chlorite and quartz. Red circle shows deformed area. (C) Zoom of part of the central zone showing corrosion of calcite and precipitation of minerals. (D) Deformation of the outer $\mathrm{Mg}$-chlorite zone and growth of Fe-chlorite and limonite after ankerite. Mineral abbreviations as in Table 1.
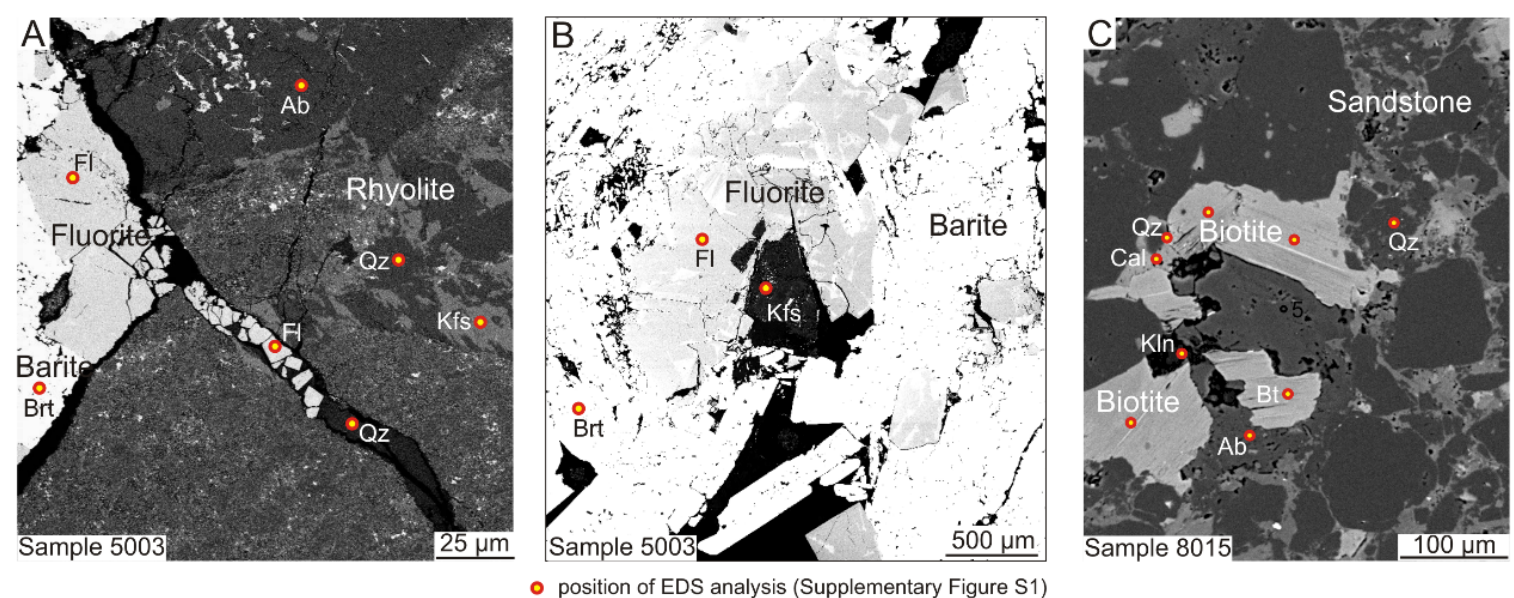

Figure 5. (A,B) Backscattered electron images of veins of fluorite and barite in rhyolite, Squally Point. (C) Secondary biotite in calcite-cemented sandstone, Five Islands. Mineral abbreviations as in Table 1. 


\subsection{Petrography of Barite Veins}

Barite in veins is generally coarse grained with tabular white or pinkish barite crystals. Some veins have euhedral calcite crystals at their margin; a few veins from Lynn Road have abundant calcite $(70 \%)$ with interstitial barite. Barite shows two orthogonal sets of cleavage in thin sections. Decrepitated fluid inclusions typically a few tens of micron in size yield EDS analyses with $\mathrm{Na}$ and $\mathrm{Cl}$ (Figure 6B). Some inclusions are strongly elongated parallel to cleavage (Figure 7C). Cataclastic barite with micron-size clasts occurs in irregular patches in and veinlets parallel to cleavage (Figure 7A,B).
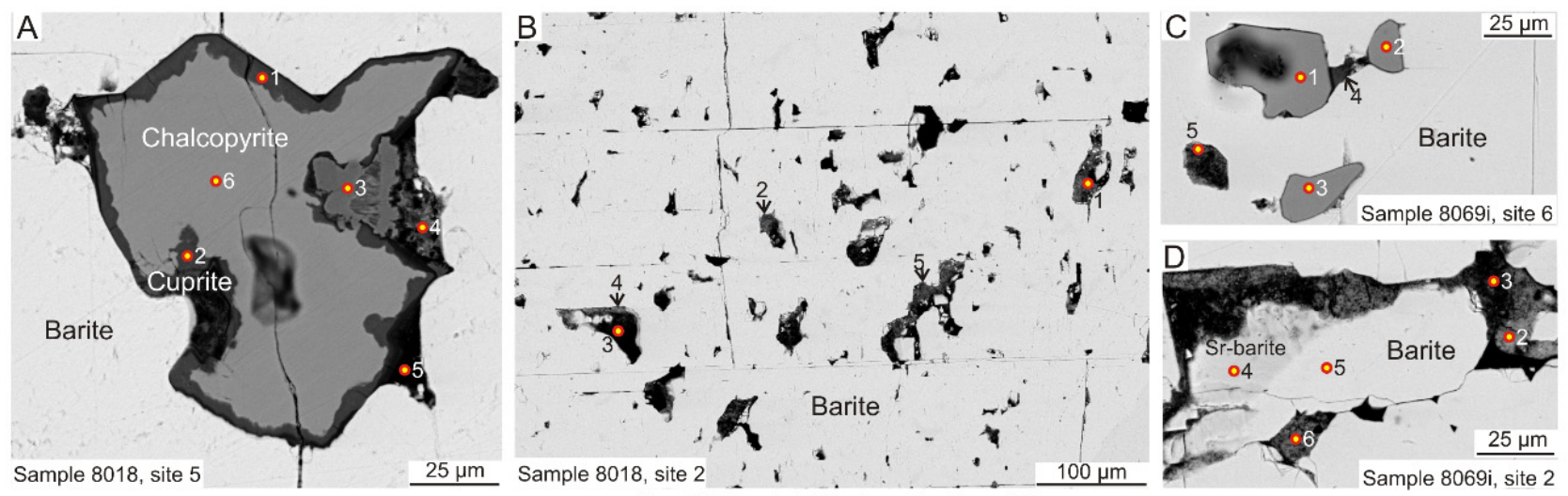

- position of EDS analysis (Supplementary Figure S2)

Figure 6. BSE images of mineral and fluid inclusions in barite veins. (A) Fractured chalcopyrite inclusion (analysis 6) with a cuprite and barite rim $(1,2)$ and engulfing pyrite (3). (B) Decrepitated fluid inclusions showing presence of trace amounts of $\mathrm{Si}, \mathrm{Al}, \mathrm{Ca}, \mathrm{Cl}, \mathrm{Na}(1,2,3,4,5)$ in various combinations. (C) Barite with anhedral chalcopyrite inclusions $(1,2,3,4)$ and decrepitated fluid inclusions (including traces of $\mathrm{Si}, \mathrm{Al}, \mathrm{Fe}, \mathrm{Na})(5)$. (D) Cluster of decrepitated fluid inclusions $(2,3,6)$ following fractures, and patches of Sr-rich barite (4).

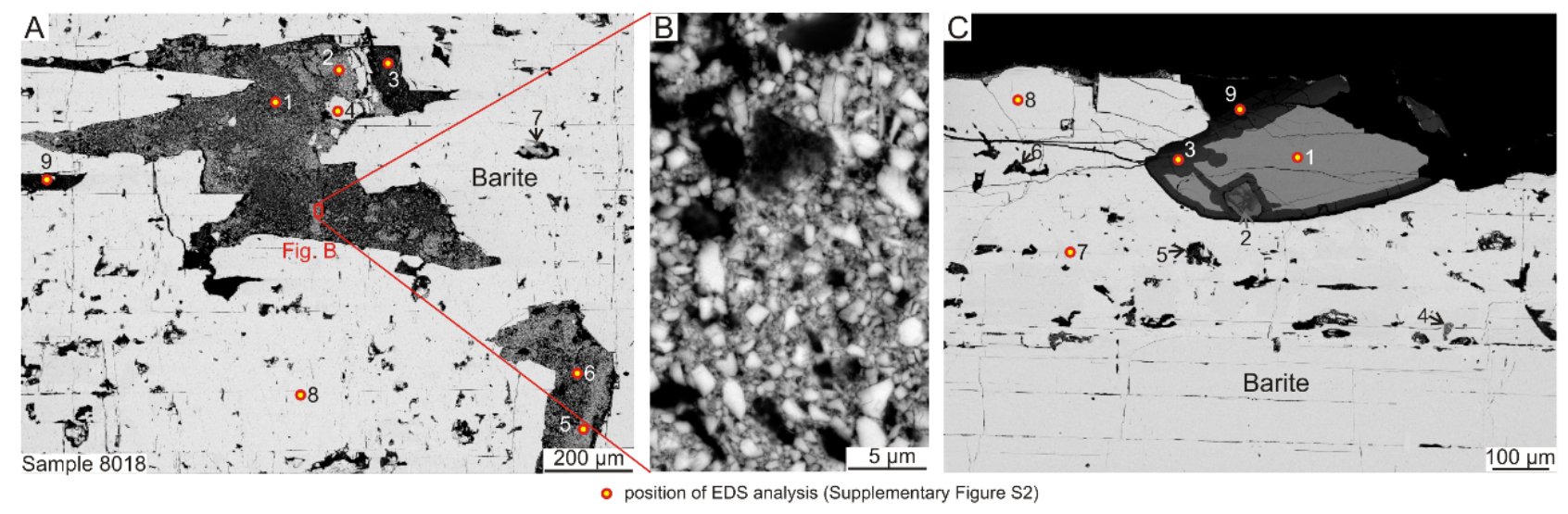

Figure 7. BSE images of cataclastic barite, chalcopyrite and pyrite in sample 8018. (A) Barite with fragmental (cataclastic) texture (1-4, 5-6) and cations in various combinations ( $\mathrm{Si}, \mathrm{Al}, \mathrm{Mg}, \mathrm{Ca}$ ) plus $\mathrm{Cl}$. (B) Zoom showing barite fragments with varying combinations of cations. (C) Barite engulfing chalcopyrite and pyrite $(1,2)$ with alteration halo made up of cuprite and limonite $(3,9)$. Fluid inclusions $(5,6)$ each show a strong alignment (horizontal in the image).

Two representative samples from barite veins, one from East River (8018) and the other from Bass River of Five Islands (8069i), were studied in detail using both BSE images and mineral analyses (Supplementary Figure S2). Barite in both samples contain chalcopyrite inclusions (Figure 6A,C), with an alteration halo at their rim enriched in Fe and Si with some $\mathrm{Al}$ and $\mathrm{Ca}$ (e.g., analysis 1 in Figure 6A). Such inclusions in a few cases engulf pyrite (Figure 6A). Chlorite inclusions (Figure 6 in Supplementary Figure S2) have FeO/MgO 1.2. Cataclastic barite in sample 8018 (Figure 7A,B) has rare quartz grains (Figure 5a in Supplementary Figure S2). Both the cataclastic barite and many decrepitated fluid 
inclusions yield EDS analyses with a few percent of the elements $\mathrm{Si}, \mathrm{Al}$, and $\mathrm{Ca}$ and in some cases $\mathrm{K}$ and $\mathrm{Fe}$. Barite contains a few discrete patches tens of microns wide with high $\mathrm{Sr}(<2.5 \mathrm{wt}$.\%) (Figure 6D; Supplementary Table S5), but otherwise $\mathrm{Sr}$ and $\mathrm{Pb}$ are below the detection limit.

\subsection{Chemistry of Barite from Five Islands}

Trace elements were determined by X-ray fluorescence (XRF) from six barite samples from the Five Islands area (Table 2$)$. Strontium is relatively abundant in all samples (1.8\% to $3.0 \%$ ). As celestite was not observed in any of the field investigations, it is probable that most of the $\mathrm{Sr}$ is in the barite lattice, where it substitutes for barium. The Sr-rich patches analysed by EDS seem to be insufficient to account for the abundance of Sr by XRF. Barite $\left(\mathrm{BaSO}_{4}\right)$ and celestite $\left(\mathrm{SrSO}_{4}\right)$ are isostructural and form a complete solid solution series [18]. Some of the lead found in each of the samples may also substitute for Ba in the barite, since anglesite $\left(\mathrm{PbSO}_{4}\right)$ and barite are also isostructural. The site of rubidium and thorium within the barites is unknown and the amount of thorium found in the samples (40 to $50 \mathrm{ppm}$ ) is high. We could not locate any Th analyses from other Nova Scotian barites, but generally vein barite is reported in the literature to normally have $<1$ ppm Th [19,20].

Table 2. Trace element content of selected barite samples by XRF.

\begin{tabular}{cccccccc}
\hline Sample & $\mathbf{7 7 9 1}$ & $\mathbf{8 0 1 8}$ & $\mathbf{8 0 2 3}$ & $\mathbf{8 0 2 5}$ & $\mathbf{8 0 6 9}$ & $\mathbf{8 0 7 9}$ & Detection Limit \\
\hline $\mathrm{Sr}$ & $2.8 \%$ & $1.8 \%$ & $2.6 \%$ & $3.0 \%$ & $2.5 \%$ & $2.7 \%$ & $0.01 \%$ \\
\hline $\mathrm{Pb}$ & 9 & 8 & 9 & 10 & 9 & 10 & $1 \mathrm{ppm}$ \\
\hline $\mathrm{Rb}$ & 10 & 8 & 11 & 11 & 10 & 11 & $1 \mathrm{ppm}$ \\
\hline $\mathrm{Th}$ & 48 & 40 & 47 & 49 & 46 & 49 & $1 \mathrm{ppm}$ \\
\hline
\end{tabular}

Strontium can enter the lattice of minerals such as calcite, fluorite and barite, and can therefore be used to constrain the genesis of such low-Rb minerals [7,21]. Strontium isotope analyses (Table 3) were made on one fluorite, two calcite, and five barite samples from the Five Islands barite veins. Within the exception of the one fluorite sample (0.7127), the samples exhibit very uniform ${ }^{87} \mathrm{Sr} /{ }^{86} \mathrm{Sr}$ ratios between 0.71021 and 0.71054 (Figure 8). Other late Carboniferous analyses from the literature are also shown in isotope plots. These include analyses from barite deposits at the Brookfield [22], Walton [23,24] and Kinsac [25] deposits and $\mathrm{Pb}-\mathrm{Zn}$ mineralization at those localities and at the Gays River and Jubilee deposits [7,26] (Figure 1a).

Sulfur and oxygen isotopes were determined on six barite samples from Five Islands. The $\delta^{34} \mathrm{~S}$ ranges from 14.0 to $16.2 \%$ o (VCDT). These analyses fall within the range of barite at Walton and are a little higher than barite from Brookfield (Figure 9). The $\delta^{18} \mathrm{O}$ ranges from 9.9 to $10.8 \%$ o (VSMOW) ( -19.5 to $-20.3 \%$ PDB). We found no oxygen isotope data for barite elsewhere, but the value is lower than that found in calcite veins at Gays River [9].

Lead isotopes were determined on one galena sample (SFB87-2016) from the N-S fractures at Five Islands. The data compare well with other late Carboniferous galenas from the Kennetcook basin (Figure 10). These galenas have $\mathrm{Pb}$ isotopes that are similar to those of late mafic rocks, including dykes cutting Horton Group in the Kennetcook basin, late gabbro in the Wentworth pluton, and the youngest basalt in the Fountain Lake Group [8]. 
Table 3. Strontium, oxygen and sulfur isotope analyses of fluorite, calcite and barite.

\begin{tabular}{|c|c|c|c|c|c|c|c|}
\hline Sample & Locality No. & Mineral & Occurrence & ${ }^{87} \mathrm{Sr} /{ }^{86} \mathrm{Sr}$ & $\begin{array}{l}\text { Uncertainty } \\
\text { (2 Sigma) }\end{array}$ & $\begin{array}{l}\delta^{18} \mathrm{O} \% \\
\text { (VSMOW) }\end{array}$ & $\begin{array}{l}\delta^{34} S \% \\
\text { (VCDT) }\end{array}$ \\
\hline 8071 & 11 & Fluorite & $\begin{array}{l}\text { breccia } \\
\text { cement }\end{array}$ & 0.71271 & 0.00002 & & \\
\hline 8071 & 11 & Calcite & $\begin{array}{l}\text { breccia } \\
\text { cement }\end{array}$ & 0.71054 & 0.00002 & & \\
\hline 8025 & 10 & Calcite & vein & 0.71045 & 0.00003 & & \\
\hline 7791 & 10 & Barite & $\begin{array}{l}\text { lenticular } \\
\text { vein }\end{array}$ & 0.71042 & 0.00002 & 10.40 & 14.60 \\
\hline 8018 & 9 & Barite & vein & 0.71047 & 0.00002 & 10.50 & 16.23 \\
\hline 8023 & 10 & Barite & $\begin{array}{l}\text { lenticular } \\
\text { vein }\end{array}$ & 0.71021 & 0.00002 & 10.80 & 14.50 \\
\hline 8025 & 10 & Barite & $\begin{array}{l}\text { lenticular } \\
\text { vein }\end{array}$ & 0.71021 & 0.00003 & 10.70 & 13.98 \\
\hline 8069 & 11 & Barite & $\begin{array}{l}\text { lenticular } \\
\text { vein }\end{array}$ & 0.71026 & 0.00002 & 9.90 & 14.28 \\
\hline 8079 & 11 & Barite & $\begin{array}{l}\text { lenticular } \\
\text { vein }\end{array}$ & & & 10.50 & 14.98 \\
\hline
\end{tabular}

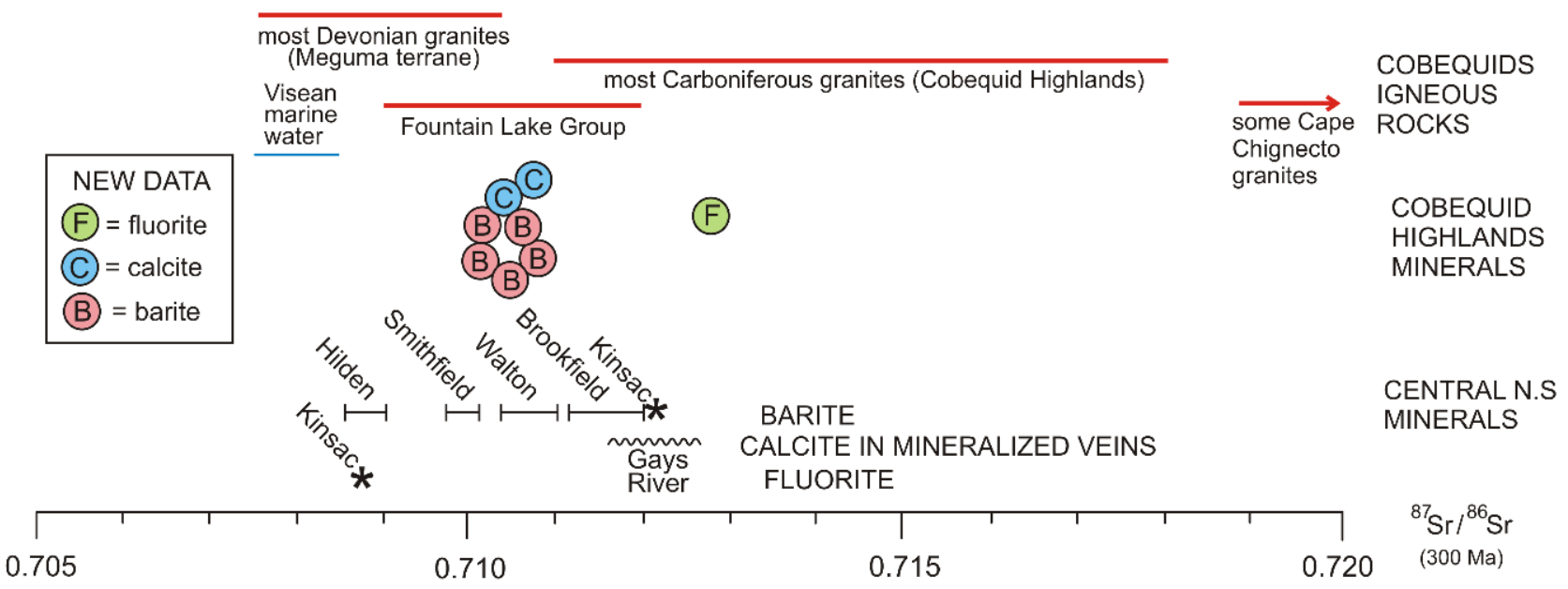

Figure 8. Initial Strontium isotope ratios. Data from Cobequid Highlands from this study; for central Nova Scotia from [7] (excluding outlier values), except [25] for Kinsac; for granites, etc., from [27,28].

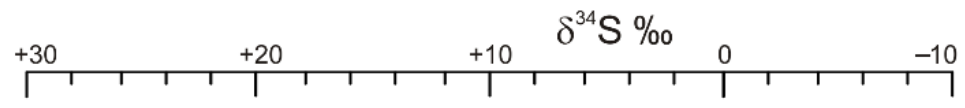

pyrite, Horton Group

anhydrite, Windsor Group

gypsum, Windsor Group

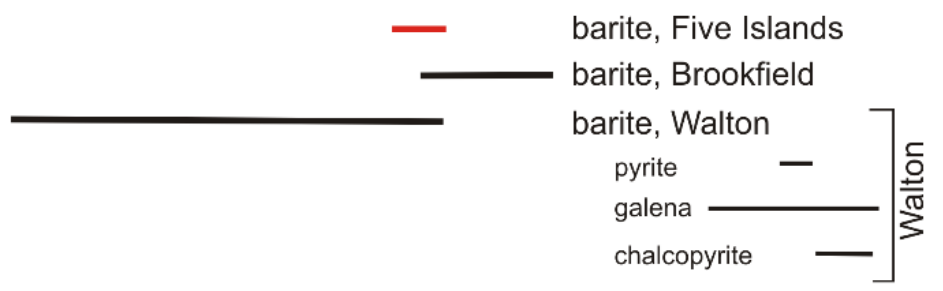

Figure 9. Sulfur isotope composition of barite and comparative rocks. Data from Cobequid Highlands from this study; for central Nova Scotia from $[23,24]$. 


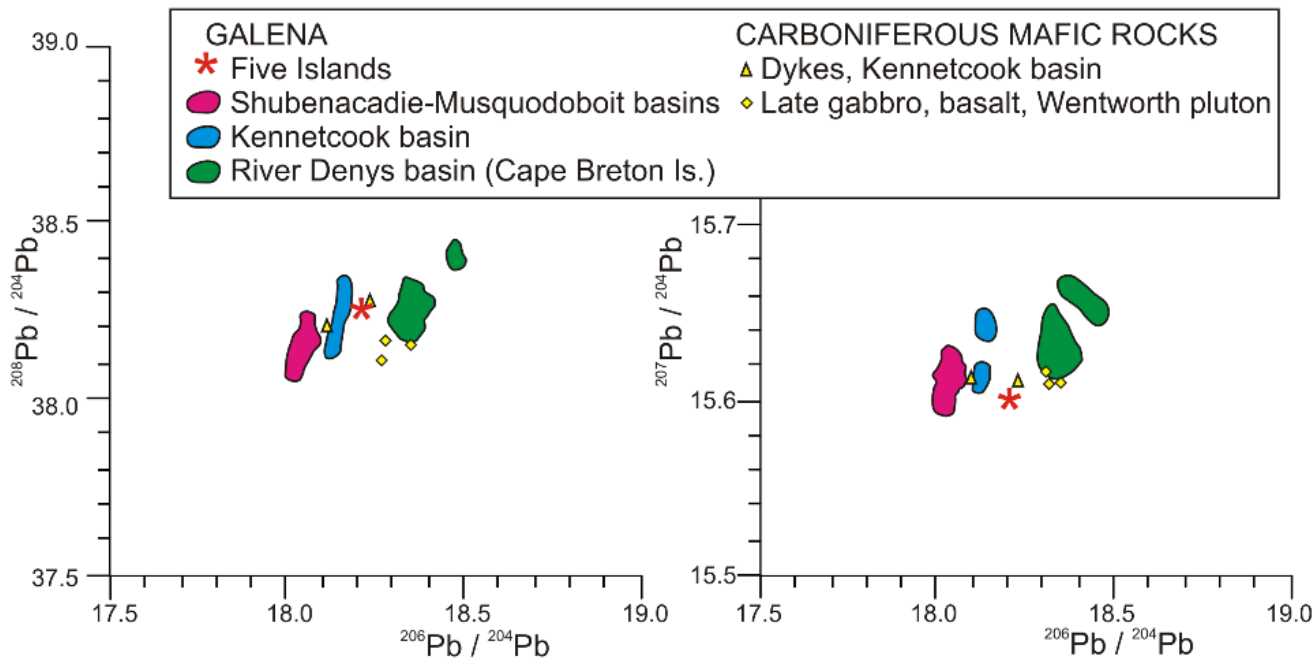

Figure 10. Lead isotope ratios from galena sample from Five Islands. Other data from galena in central Nova Scotia from [26]. Selected mafic rocks from [6].

\subsection{Chemistry of Host Rocks from Five Islands}

Petrographic studies of argillites and sandstones show that many have mm-scale tension gashes or small veins filled with quartz and/or calcite. Samples identified as altered also show calcite replacement of detrital plagioclase and an alteration halo of chlorite around tension gashes. Most argillites and many sandstones contain 1-2\% hematite and argillites have $1-5 \%$ pyrite and in a few samples also minor chalcopyrite. Small veins in sandstones may have minor muscovite or chlorite.

Comparison of bulk chemical composition between altered and fresh host rock is evaluated according to distance from barite veins (Figure 11). There appears to be no relationship between Ba content and proximity to barite veins, consistent with the field observation that there is no systematic alteration halo adjacent to barite veins. The barite veins intruded country rock that had already been cut by different sets of mineralized veins. There is no systematic enrichment for any element except $\mathrm{Ca}$ in samples identified as altered, not even for Fe despite the observations of hematite and pyrite. Some altered samples show enrichment or depletion in $\mathrm{K}, \mathrm{Na}$ and $\mathrm{Mg}$, probably reflecting relative amounts of secondary muscovite, albite and chlorite, respectively. 

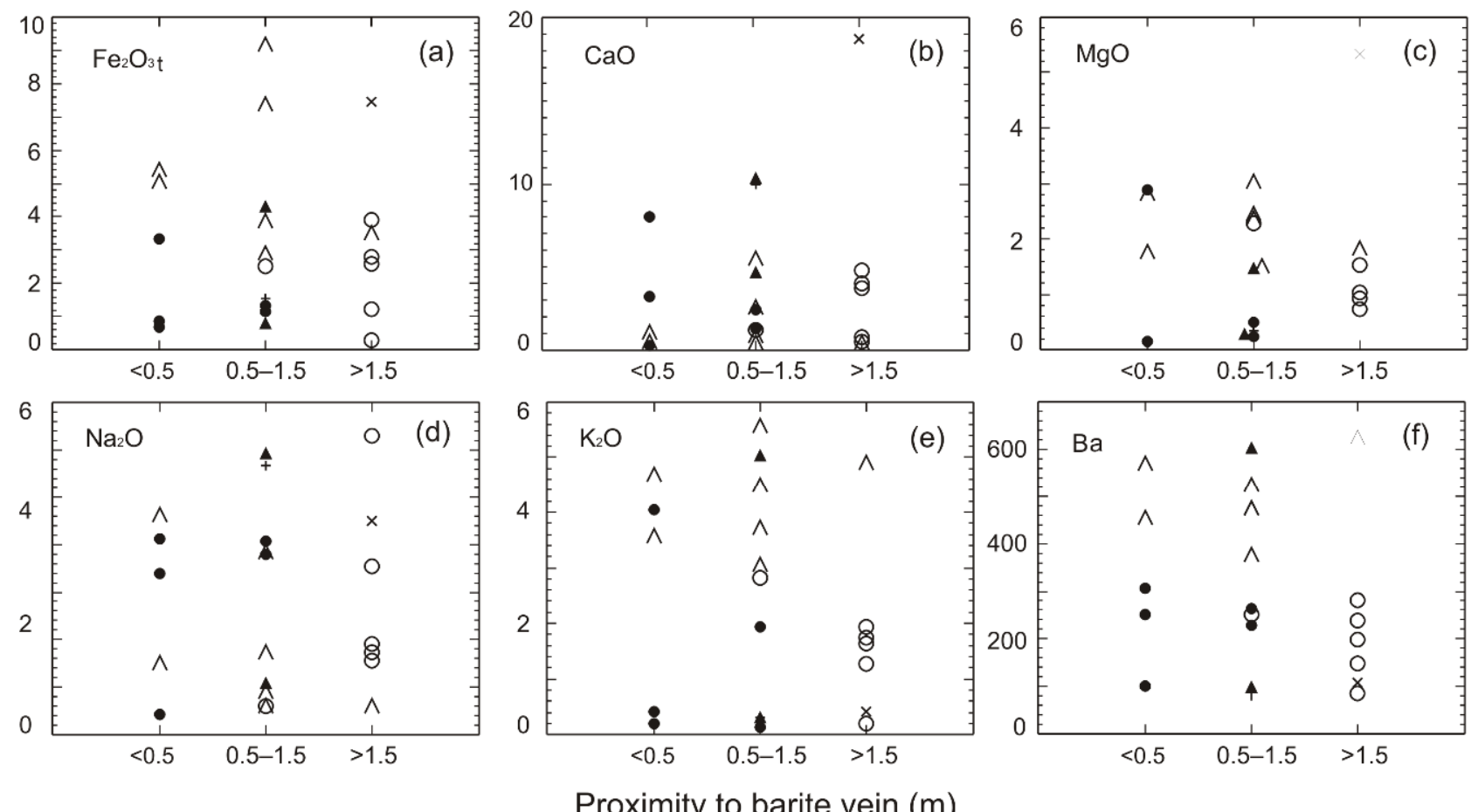

Proximity to barite vein $(\mathrm{m})$

$\begin{array}{|lll|}\wedge \text { fresh argillite } & \Delta \text { altered argillite } & \times \text { calcareous argillite } \\ \circ \text { fresh sandstone } & \bullet \text { altered sandstone } & + \text { calcareous sandstone }\end{array}$

Figure 11. Geochemical composition of Horton Group host rocks compared with distance from barite veins, from the area north of Five Islands (localities 9-15). (a-f) show plots for different elements.

\section{Discussion}

\subsection{Paragenesis of Veins Older Than the Barite Veins}

We have used mineral textural relationships to establish the paragenetic sequence of the veins that cut the Horton Group sandstones and argillites (Figure 12). The relative ages of these mineral veins are consistent with the dated sequence of vein minerals mostly in Horton Group rocks along the Cobequid Fault from Lynn Road to West Advocate [6] (Figure $1 b$ ). In this sequence, albite veins seem to be the oldest, but overlap in age with quartz-chlorite veins and potassic alteration (producing secondary biotite) and are followed by calcite ( \pm dolomite) veins, ranging in age from ca. 355 Ma to ca. 330 Ma during progressive deformation along the Cobequid Shear Zone (Figure 12). A very different mineral assemblage, in places occupying new fractures, is recognised following the onset of E-W deformation on the Minas Fault Zone at ca. $327 \mathrm{Ma}$. This assemblage includes pyrite, ankerite, hematite and magnetite, and younger titania, zircon and REE minerals, which were not noted in the barite veins at Five Islands. In general, the Fe-rich mineralization is not well developed in the Five Islands country rock, but farther west trace amounts of barite post-date alteration of ankerite to limonite and partial dissolution of titania in mineral vein fills (Supplementary Table S1). The fluorite-barite veins studied are located directly in country rock rather than being associated with older veins. This suggests a deformation phase with a different stress field from that earlier in the Carboniferous.

\subsection{Geochronologic Constraints on Timing of the Barite Veins}

The timing of emplacement of barite veins is poorly constrained (Figure 12). At Lynn Road, imprecise U-Pb ages were obtained from REE-rich allanite (313 $\pm 7 \mathrm{Ma}$ ) and monazite (320 $\pm 7 \mathrm{Ma})$, apparently older than the Five Islands barite [6]. The Pb-Zn-Mn-Ba mineralization at the Walton mine is younger than the emplacement of the Cheverie dyke, 
which has similar mineralization, where fresh dyke rock was dated at $319 \pm 4$ Ma [29] (when corrected to modern standards as in [6]). The published $\mathrm{Rb}-\mathrm{Sr}$ isochron age of $300 \pm 6 \mathrm{Ma}$ on altered Horton Group rocks [7] is interpreted as the last time that there was flow of hydrothermal fluids with $\mathrm{Sr}$, and thus probably corresponds to the youngest barite precipitation event. The barite at Spicer Cove postdates deposition and deformation of the upper Ragged Reef Formation, dated as late Bashkirian (ca. $314 \mathrm{Ma}$ ) [16,30]. The possibility of a much younger age within the Carboniferous or even early Permian cannot be ruled out.

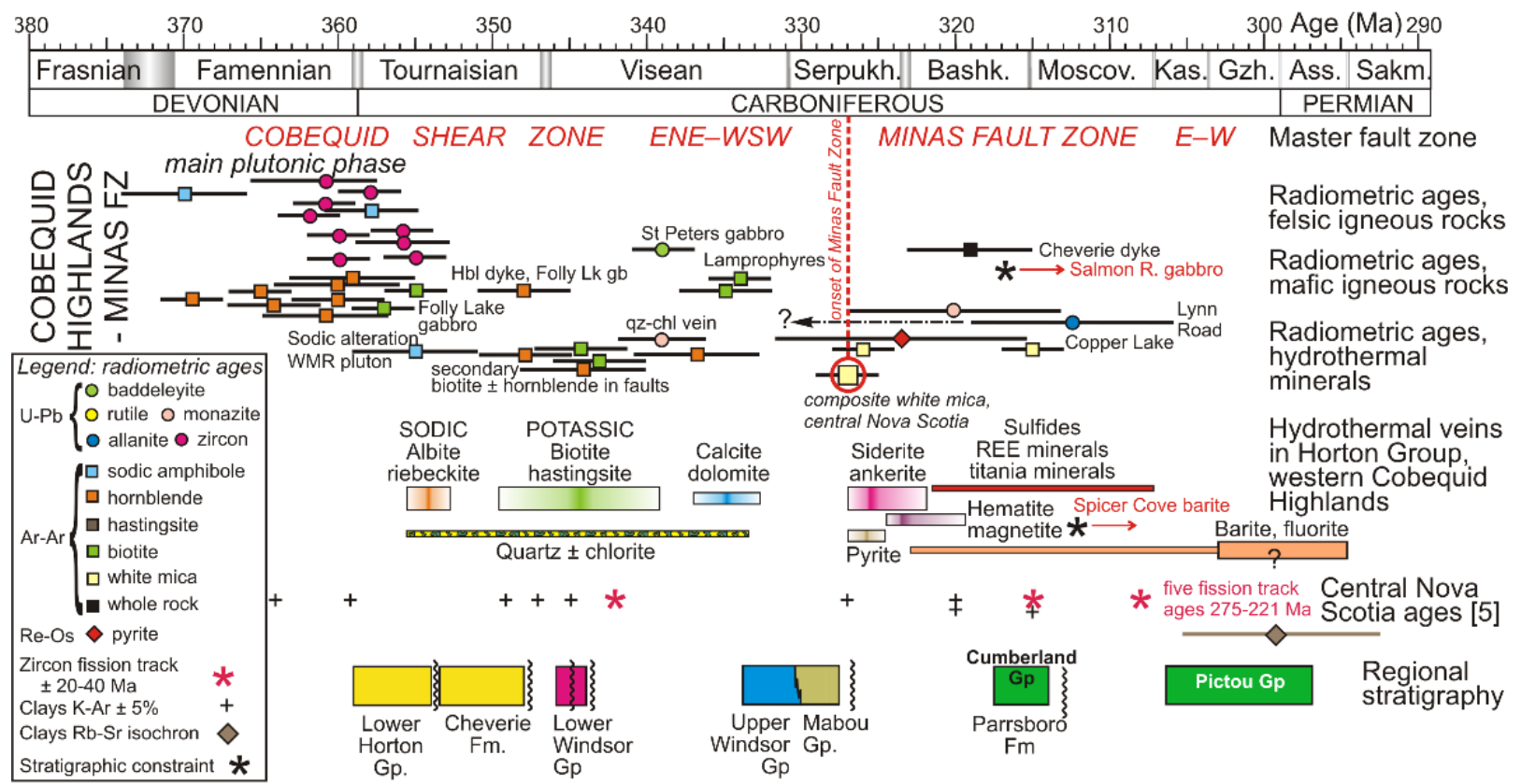

Figure 12. Timeline for mineral veins in Carboniferous rocks of the Cobequid Highlands.

\subsection{Relationship of Barite to $\mathrm{Pb}-\mathrm{Zn}$ Sulfide and Fe-Mn Oxide Mineralization}

Barite is commonly associated with Mississippi Valley type $\mathrm{Pb}-\mathrm{Zn}$ mineralization and in the Carboniferous basins of Nova Scotia barite has been regarded as co-genetic with $\mathrm{Zn}$ and $\mathrm{Pb}$ mineralization [22,24,31]. In the Walton deposit (Figure 1a), rare type 3 barite is described as intergrown with sulfides, perhaps by replacement of pre-existing siderite; types 1 and 2 barite show no distinctive relationship with sulfides, type 4 cross-cuts types 1-3, and type 5 lines vugs [24]. At Brookfield (Figure 1a), barite occurs in the centre of siderite veins and some barite veins cross-cut earlier deformed barite and siderite veins in which the two minerals appear intergrown [22].

Ankerite-siderite-magnetite mineralization is widespread along the Minas Fault Zone [6], including the large ankerite deposit at Londonderry (Figure 1a) with supergene enrichment to goethite and specularite. Nineteenth-century quarries, now overgrown, showed the iron ores cut by barite veins [32] and barite veinlets cut host sandstone [1]. At the East Mountain mine, barite fills vugs in the main pyrolusite-manganite deposit [3].

In the western Cobequid Highlands, studies of sequential vein fills [33] (p. 84, Figure 21D) show rare textural evidence for both galena and barite being late in the mineral paragenesis. Prospectors reports of localities 18 and 19 (Table 1) suggest mineral showings with galena, sphalerite and barite [34]. On the other hand, in the Five Islands area (occurrences 9-15, Table 1) barite is found in E-W brecciated fault zones lacking galena and sphalerite, and rare showings of galena and sphalerite are either stratabound or on N-S faults (localities 226, 227, 233, 234, 239 of [3]).

Thus the field occurrence of barite suggests that some barite veins are genetically related to $\mathrm{Pb}-\mathrm{Zn}$ mineralization, but many barite occurrences post-date ankerite-sideritemagnetite mineralization and $\mathrm{Pb}-\mathrm{Zn}$ mineralization. Analyses of decrepitated fluid inclu- 
sions (Figure 6) and fluid inclusion studies at Brookfield [22] indicate an important role for Lower Carboniferous evaporites in the mineralizing process. The Sr isotope results suggest that the mineralizing fluids exchanged with a radiogenic source, with the arkosic Horton Group being generally interpreted as the most likely reservoir. The similarity of Sr isotopes (Figure 8) and S isotopes (Figure 9) in barite from Five Islands compared with data from Walton and Brookfield is also evidence for a common source.

\subsection{Relationship of Barite Veins to Granites}

There is a clear geographic relationship between the presence of late Devonian-earliest Carboniferous granite and the occurrence of barite veins (Figure 1b). Clusters of barite occurrences are found south of the Wentworth pluton, near the Pleasant Hills and North River plutons, close to the large granite dykes east of the Hanna Farm pluton [35] (p. 227), and north of the Cape Chignecto pluton. These plutons have experienced pervasive brittle deformation and fracturing through the Carboniferous [17,36] and have bulk rock contents of Ba averaging only a few hundred ppm. The uniformity of Sr and S isotopes, regardless of proximity to granite plutons, suggests that the granite was not a significant source of Ba. Furthermore, $\mathrm{Pb}$ isotopes suggest that substantial supply of $\mathrm{Pb}$ from the rather radiogenic granites [8] is unlikely. Rather, during regional deformation, sub-surface rooted granites deformed in a brittle manner providing pathways for mineralizing fluids. In contrast, in the intervening sedimentary rocks, commonly steeply dipping and cut by subvertical faults, deformation was more widely distributed.

\subsection{The Significance of Fluorite}

Globally, barite commonly co-occurs with fluorite [37] and these two minerals are characteristically found together in the Five Islands and Squally Point localities, but fluorite is absent farther east (localities 1-8, Table 1). Other evidence for abundant fluorine in late Carboniferous fluids is provided by the distribution of minor amounts of a $\mathrm{TiO}_{2}$ mineral phase, zircon and some REE-fluorocarbonates in vein fills younger than ankerite and magnetite [6] (Figure 12). All these late minerals have mobility and precipitation favoured by abundant F [38-40] (respectively). The reason for evidence of high F in the late Carboniferous is unclear. In the early Carboniferous, alteration of amphibole and biotite in plutons has been proposed as a source of F [40]. In fluorite-barite deposits in the Rio Grande Rift (New Mexico, USA), the F has been shown to be derived from upwelling asthenosphere $[41,42]$. There, the $\mathrm{F}$ is associated with low $\mathrm{pH}$ magmatic fluids, which mixed with sedimentary brines and sulfide precipitation was inhibited by the low $\mathrm{pH}$. Why $\mathrm{F}$ is more abundant in the later mineralization of the western Cobequid Highlands, compared to the east, remains unknown.

\subsection{Events Younger Than the Barite Veins}

The barite veins in the field are locally cut by NW-SE shears with calcite veins. Some barite veins also have euhedral calcite at their margin. At a microscopic level, the latest mineral phases to precipitate in almost open fractures include chlorite and kaolinite (Figure 5). Similar late open fractures with chlorite and kaolinite are found elsewhere in the Horton Group along the Minas Fault Zone (e.g., Lynn Road, [33]). The presence of trace amounts of $\mathrm{Si}, \mathrm{Al}$, and Fe in decrepitated fluid inclusions and cataclastic zones in barite veins suggest the percolation of late chlorite and kaolinite into barite veins along fractures and opened cleavage. The high Th content of barite veins may be of similar origin. The presence of cataclastic patches in barite veins, presumably the result of hydraulic fracturing based on its geometry, suggests a late overpressured fluid event. In the Bass River of Five Islands, some faults parallel to the barite veins contain a fault pug decimeters thick, comprising altered cataclastic country rock loosely cemented by quartz and calcite.

The timing of the late kaolinite and chlorite is unknown. Continuing fault movement along the Minas Fault Zone is assumed for the Permian and clearly demonstrable for the Triassic (particularly late Triassic) and early Cretaceous [43]. Kaolinite is unlikely under 
arid conditions in the Permian, but has been recorded in both Triassic and particularly Cretaceous mudstones [44]. Fluids favouring precipitation of chlorite could be related to the North Mountain Basalt of late Triassic age [43].

\subsection{Tectonosedimentary History of Carboniferous Mineralization}

Two aspects of the Lower Carboniferous sedimentation south of the Cobequid Highlands played an important role in the history of mineralization in the region (Figure 13). First, the Horton Group includes arkosic sandstones and thick organic rich shale successions, which during mid-Carboniferous thrusting in the Kennetcook Basin [45] produced overpressured formation waters, presumably with considerable amounts of Ba from feldspars and $\mathrm{HCO}_{3}{ }^{-}$from breakdown of organic matter $[9,26]$. Second, the abundance of halite and gypsum in the lower Windsor Group provided abundant $\mathrm{Cl}^{-}$and $\mathrm{SO}_{4}{ }^{2-}$ anions that at elevated temperatures complexed with metallic cations.

Along the northern margin of the basin, igneous rocks provided an important heat source throughout the late Devonian and early Carboniferous (Figure 12). Even in the late Carboniferous, two mafic intrusions are known, one dating from $319 \mathrm{Ma}$ [29] and one $315 \mathrm{Ma}$ or younger [46]. Thus, associated with this continental-scale shear zone there was a prolonged heat source to drive hydrothermal circulation. The sequence of sodic, potassic and carbonate vein minerals in the early Carboniferous (Figure 12) may represent relatively local circulation of fluids.

The major change in mineralization at the mid-Carboniferous unconformity can be related to overthrusting in the Kennetcook Basin [45] and the migration of overpressured fluids along the newly formed Minas Fault Zone. The occurrence of the large ankerite deposit at Londonderry and magnetite at Bass River (Figure 1b) close to the Folly Lake gabbro, the largest ferrogabbro intrusion in the Appalachians, is unlikely to be coincidental. Even the $\mathrm{Pb}$ isotope composition of galena in the Kennetcook Basin (Figure 10) is close to the composition of late mafic rocks in the region.

In central Nova Scotia, the availability of Windsor Group evaporites favoured the occurrence of $\mathrm{Pb}-\mathrm{Zn}$ mineralization, with significant $\mathrm{Fe}$ and $\mathrm{Mn}$ mineralization at Walton and Brookfield, including some barite. As reviewed above, much of the barite in these two deposits appears to be late in the paragenetic sequence. As igneous activity waned and the geothermal gradient diminished, higher-temperature sulfides and carbonates were no longer transported in hydrothermally circulating fluids, but with the availability of $\mathrm{SO}_{4}{ }^{2-}$, barite became the dominant mineral even at relatively low temperatures. Solubility of barite diminishes rapidly at temperatures below $100^{\circ} \mathrm{C}$ [47]. The source of Ba might have been from the breakdown of detrital feldspar in sandstone during burial to depths $>2 \mathrm{~km}$ as Upper Carboniferous sediment continued to accumulate in the region immediately south of the Minas Fault Zone (Figure 1b), similar to the interpreted source for $\mathrm{Pb}$ in galena in central Nova Scotia [26]. 
NORTH

SOUTH

Fountain Lake

volcanics Kirkhill

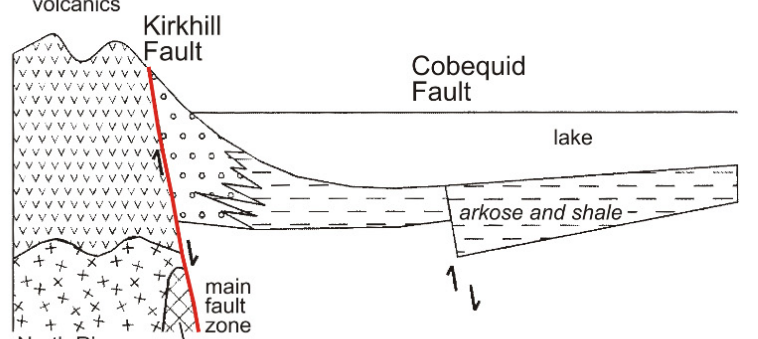

granite pluton $Y_{\text {gabbro }}$
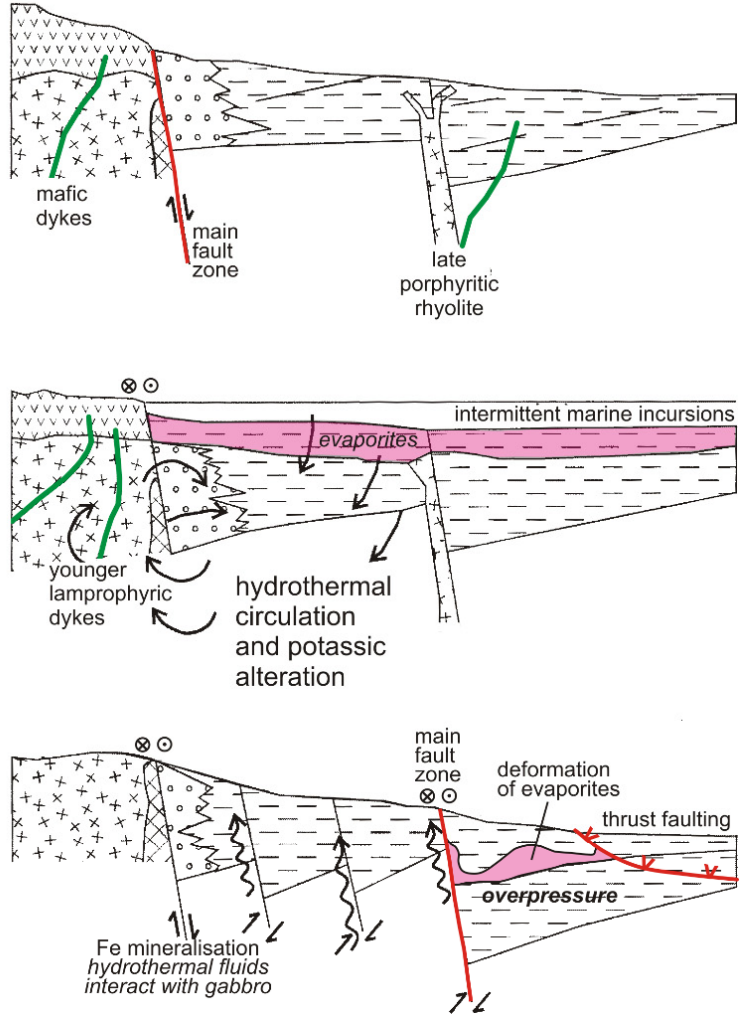

$\mathrm{Pb}-\mathrm{Zn}-\mathrm{Mn}$ mineralisation
hot saline fluids from basin

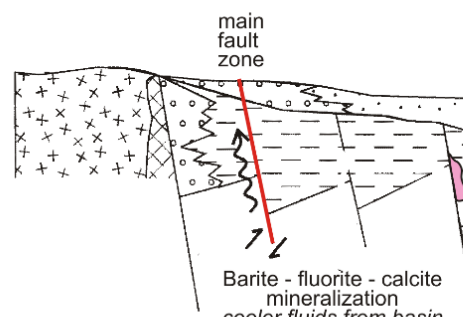

mineralization (a) Main pluton emplacement

$\sim 362 \mathrm{Ma}$

early Horton Group deposition

(b) Late igneous phases

$\sim 355 \mathrm{Ma}$

unconformity within Horton Group

sodic alteration (c) Potassic alteration driven by renewed tectonic activity and late mafic dykes $\sim 340 \mathrm{Ma}$

end of Windsor Group evaporite deposition

(d) Onset of dextral movement on E-W Minas Fault Zone

$327 \mathrm{Ma}$

widespread mineralization in central Nova Scotia

(e) Early Permian uplift $\sim 300 \mathrm{Ma}$

Change in stress field

Low temperature

mineralization

Figure 13. (a-e) Sequential evolution of the southern of the Cobequid Highlands through the Carboniferous.

\section{Conclusions}

1. Veins of barite, associated with fluorite and/or calcite, represent the youngest and probably coolest phase of a 70 Ma history of Carboniferous mineralized veins along the Minas Fault Zone. Their prominence close to granite plutons reflects brittle deformation of the deeply-rooted granites in a complexly deforming fault zone creating pathways for mineralizing fluids. 
2. Many barite occurrences in the Carboniferous basins of central Nova Scotia postdate ankerite-siderite-magnetite-pyrolusite mineralization and $\mathrm{Pb}-\mathrm{Zn}$ mineralization, some of which is younger than $319 \mathrm{Ma}$. Stratigraphic control shows that some barite is younger than $315 \mathrm{Ma}$. The published $\mathrm{Rb}-\mathrm{Sr}$ isochron of $300 \pm 6 \mathrm{Ma}$ [7] marks the youngest significant $\mathrm{Sr}$ mobility event, likely related to barite emplacement.

3. The isotope chemistry of barite and associated fluorite and calcite is similar to that occurring in $\mathrm{Pb}-\mathrm{Zn}-\mathrm{Mn}-\mathrm{Ba}$ mineralization, suggesting a role for fluids derived from evaporite deposits in the Lower Carboniferous basins of central Nova Scotia.

4. In the western part of the Minas Fault Zone, the availability of F played an important role in the fill of veins by a late titania mineral, zircon, and REE fluorocarbonates. Comparison with Rio Grande Rift fluorite-barite deposits suggests the possibility of a mantle source for $\mathrm{F}$. The precipitation of barite but no sulfides might reflect either relatively low temperatures $\left(100-140^{\circ} \mathrm{C}\right)$ or low $\mathrm{pH}$.

Supplementary Materials: The following are available online at https:/ /www.mdpi.com/article/ 10.3390/min11121413/s1, Figure S1: SEM data on host rocks, Figure S2: SEM data on barite veins, Table S1: Barite mode of occurrence, Table S2: Country rock XRF geochemistry, Table S3: Chlorite EDS geochemistry, Table S4: Biotite EDS geochemistry, Table S5: Barite EDS geochemistry.

Author Contributions: Conceptualization, G.P.-P.; Funding acquisition, G.P.-P.; Investigation, G.P.-P. and D.J.W.P.; Methodology, G.P.-P.; Writing—original draft, G.P.-P. and D.J.W.P.; Writing—review \& editing, G.P.P. and D.J.W.P. All authors have read and agreed to the published version of the manuscript.

Funding: This research was funded by Natural Sciences and Engineering Research Council of Canada (NSERC) discovery grants to G. Pe-Piper, most recently grant no. 2016-04310.

Data Availability Statement: Data are available in the published paper and Supplementary Materials.

Acknowledgments: David Pass and Jason Goulden assisted with field work and Isabel Chavez with lab work.

Conflicts of Interest: The authors declare no conflict of interest.

\section{References}

1. Felderhof, G.W. Barite, Celestite and Fluorite in Nova Scotia; Province of Nova Scotia, Department of Mines: Halifax, NS, Canada, 1978; pp. 1-463.

2. Donohoe, H.V. Mineral Occurrences in the Cobequid Highlands; Nova Scotia Department of Mines and Energy: Halifax, NS, Canada, 1982; pp. 79-111.

3. Ervine, W.B. Mineral Occurrences along the Cobequid-Chedabucto Fault System, Nova Scotia; Natural Resources Canada: Ottawa, ON, Canada, 1994; pp. 1-503.

4. Murphy, J.B.; Waldron, J.W.G.; Kontak, D.J.; Pe-Piper, G.; Piper, D.J.W. Minas Fault Zone: Late Paleozoic history of an intracontinental orogenic transform fault in the Canadian Appalachians. J. Struct. Geol. 2011, 33, 312-328. [CrossRef]

5. Hibbard, J.; Waldron, J.W.G. Truncation and translation of Appalachian promontories: Mid-Paleozoic strike-slip tectonics and basin initiation. Geology 2009, 37, 487-490. [CrossRef]

6. Pe-Piper, G.; Piper, D.J.W.; McFarlane, C.R.; Sangster, C.; Zhang, Y.; Boucher, B. Petrology, chronology and sequence of vein systems: Systematic magmatic and hydrothermal history of a major intracontinental shear zone, Canadian Appalachians. Lithos 2018, 304, 298-310. [CrossRef]

7. Ravenhurst, C.E.; Reynolds, P.H.; Zentilli, M.; Krueger, H.W.; Blenkinsop, J. Formation of Carboniferous Pb-Zn and barite mineralization from basin-derived fluids, Nova Scotia, Canada. Econ. Geol. 1989, 84, 1471-1488. [CrossRef]

8. Pe-Piper, G.; Piper, D.J.W. Geochemical evolution of Devonian-Carboniferous igneous rocks of the Magdalen basin, Eastern Canada: Pb-and Nd-isotope evidence for mantle and lower crustal sources. Can. J. Earth Sci. 1998, 35, 201-221. [CrossRef]

9. Sangster, D.F.; Savard, M.M.; Kontak, D.J. A genetic model for mineralization of Lower Windsor (Visean) carbonate rocks of Nova Scotia, Canada. Econ. Geol. 1998, 93, 932-952. [CrossRef]

10. Piper, D.J.W.; Pe-Piper, G.; Pass, D.J. The stratigraphy and geochemistry of late Devonian to early Carboniferous volcanic rocks of the northern Chignecto peninsula, Cobequid Highlands, Nova Scotia. Atl. Geol. 1996, 32, 39-52. [CrossRef]

11. Whitney, D.L.; Evans, B.W. Abbreviations for names of rock-forming minerals. Am. Mineral. 2010, 95, 185-187. [CrossRef]

12. Pe-Piper, G. Mineralogy of an Appinitic Hornblende Gabbro and Its Significance for the Evolution of Rising Calc-Alkaline Magmas. Minerals 2020, 10, 1088. [CrossRef] 
13. Actlabs. Available online: https://actlabs.com/geochemistry/lithogeochemistry-and-whole-rock-analysis/lithogeochemistry/ (accessed on 27 November 2021).

14. Koukouvelas, I.; Pe-Piper, G.; Piper, D.J.W. Pluton emplacement by wall-rock thrusting, hanging-wall translation and extensional collapse: Latest Devonian plutons of the Cobequid fault zone, Nova Scotia, Canada. Geol. Mag. 1996, 133, 285-298. [CrossRef]

15. Ryan, R.J.; Boehner, R.C.; Deal, A. Cumberland Basin Geology Map, Apple River and Cape Chignecto, Cumberland County, Map 90-11, 1: 50000 Scale; Nova Scotia Department of Mines and Energy: Halifax, NS, Canada, 1990.

16. Utting, J.; Giles, P.; Dolby, G. Palynostratigraphy of the Mississippian and Pennsylvanian rocks, Joggins area, Nova Scotia and New Brunswick, Canada. Palynology 2010, 34, 43-89. [CrossRef]

17. Pe-Piper, G.; Piper, D.J.W.; Papoutsa, A.; Wisen, J. Fractured latest Devonian granites of the West Moose River pluton along the Cobequid Shear Zone, Nova Scotia: Implications for regional mineralization. Can. J. Earth Sci. 2017, 51, 1119-1137. [CrossRef]

18. Nesse, W.D. Introduction to Optical Mineralogy, 2nd ed.; Oxford University Press: Oxford, UK, 1991; pp. $154-155$.

19. Mills, J.W. Bedded barite deposits of Stevens County, Washington. Econ. Geol. 1971, 66, 1157-1163. [CrossRef]

20. Howie, R.A.; Zussman, J.; Deer, W.A. An introduction to the Rock-Forming Minerals; Longman: London, UK, $1992 ;$ p. 696.

21. Barbieri, M.; Masi, U.; Tolomeo, L. Strontium geochemical evidence for the origin of the barite deposits from Sardinia, Italy. Econ. Geol. 1984, 79, 1360-1365. [CrossRef]

22. Kontak, D.J.; Kyser, K.; Gize, A.; Marshall, D. Structurally controlled vein barite mineralization in the Maritimes Basin of eastern Canada: Geologic setting, stable isotopes, and fluid inclusions. Econ. Geol. 2006, 101, 407-430. [CrossRef]

23. Boyle, R.W.; Wanless, R.K.; Stevens, R.D. Sulfur isotope investigation of the barite, manganese, and lead-zinc-copper-silver deposits of the Walton-Cheverie area, Nova Scotia, Canada. Econ. Geol. 1976, 71, 749-762. [CrossRef]

24. Kontak, D.J.; Sangster, D.F. Aqueous and liquid petroleum inclusions in barite from the Walton Deposit, Nova Scotia, Canada; a Carboniferous, carbonate-hosted Ba-Pb-Zn-Cu-Ag deposit. Econ. Geol. 1998, 93, 845-868. [CrossRef]

25. Kontak, D.; Horne, R.; Ansdell, K.; Archibald, D. Carboniferous barite-fluorite mineralization in the Late Devonian Kinsac pluton, southern Nova Scotia. Atl. Geol. 1999, 35, 109-127. [CrossRef]

26. Sangster, D.F.; Savard, M.M.; Kontak, D.J. Sub-basin-specific Pb and Sr sources in Zn-Pb deposits of the lower Windsor Group, Nova Scotia, Canada. Econ. Geol. 1998, 93, 911-919. [CrossRef]

27. Pe-Piper, G.; Cormier, R.F.; Piper, D.J.W. The age and significance of Carboniferous plutons of the western Cobequid Highlands, Nova Scotia. Can. J. Earth Sci. 1989, 26, 1297-1307. [CrossRef]

28. Clarke, D.B.; Halliday, A.N. Strontium isotope geology of the South Mountain batholith, Nova Scotia. Geochim. Cosmochim. Acta 1980, 44, 1045-1058. [CrossRef]

29. Kontak, D.; Ansdell, K.; Archibald, D. Zn-Pb mineralization associated with a mafic dyke at Cheverie, Hants County, Nova Scotia: Implications for Carboniferous metallogeny. Atl. Geol. 2000, 36, 7-26. [CrossRef]

30. Pointon, M.A.; Chew, D.M.; Ovtcharova, M.; Sevastopulo, G.D.; Crowley, Q.G. New high-precision U-Pb dates from western European Carboniferous tuffs; implications for time scale calibration, the periodicity of late Carboniferous cycles and stratigraphical correlation. J. Geol. Soc. 2012, 169, 713-721. [CrossRef]

31. Ravenhurst, C.E.; Reynolds, P.H.; Zentilli, M. Strontium isotopic studies of rock and mineral samples in the Shubenacadie Basin, Nova Scotia. Curr. Res. Part B Geol. Surv. Can. Pap. 1986, 86, 547-555.

32. Louis, H. On the ankerite veins of Londonderry, Nova Scotia. Proc. Nova Scotian Inst. Sci. 1879, 5, 47-57.

33. Pe-Piper, G.; Piper, D.J.W.; Zhang, Y.; Sangster, C. Hydrothermal alteration of fractured Carboniferous sedimentary rocks along the Cobequid Fault Zone, western Nova Scotia. Geol. Surv. Can. Open File 2017, 8102, 724. [CrossRef]

34. Hudgins, A.D. NSDNR, MRB, Bulletin ME 4, Barite, Celestite and Fluorite in Nova Scotia; Assessment Report ME 21H/08C 27-E-25; Nova Scotia Department of Natural Resources: Baddeck, NS, Canada, 1970.

35. Piper, D.J.W.; Pe-Piper, G.; Loncarevic, B.D. Devonian-Carboniferous igneous intrusions and their deformation, Cobequid Highlands, Nova Scotia. Atl. Geol. 1993, 29, 219-232. [CrossRef]

36. Piper, D.J.W.; Pe-Piper, G. Evolution of late Paleozoic shearing in the Cobequid Highlands: Constraints on the fragmentation of the Appalachian Orogen in Nova Scotia along intra-continental shear zones. Geol. Soc. Lond. Spec. Publ. 2021, 503, 423-442. [CrossRef]

37. Van Alstine, R.E. Continental rifts and lineaments associated with major fluorspar districts. Econ. Geol. 1976, 71, 977-987. [CrossRef]

38. Yu, J.C.; Ho, W.; Yu, J.; Hark, S.K.; Lu, K. Effects of trifluoroacetic acid modification on the surface microstructures and photocatalytic activity of mesoporous $\mathrm{TiO}_{2}$ thin films. Langmuir 2003, 19, 3889-3896. [CrossRef]

39. Bojanowski, M.J.; Bagin'ski, B.; Clarkson, E.; Macdonald, R.; Marynowski, L. Low-temperature zircon growth related to hydrothermal alteration of siderite concretions in Mississippian shales, Scotland. Contrib. Mineral. Petrol. 2012, 164, 245-259. [CrossRef]

40. Papoutsa, A.; Pe-Piper, G. Variation of REE-hydrothermal circulation in complex shear zones: The Cobequid Highlands, Nova Scotia. Can. Mineral. 2014, 52, 943-968. [CrossRef]

41. Partey, F.; Lev, S.; Casey, R.; Widom, E.; Lueth, V.W.; Rakovan, J. Source of fluorine and petrogenesis of the Rio Grande rift-type barite-fluorite-galena deposits. Econ. Geol. 2009, 104, 505-520. [CrossRef]

42. Smith-Schmitz, S.E.; Appold, M.S. Determination of fluorine concentrations in mineralizing fluids of the Hansonburg, New Mexico Ba-F-Pb district via SEM-EDS analysis of fluid inclusion decrepitates. J. Geochem. Explor. 2021, 230, 106861. [CrossRef] 
43. Withjack, M.O.; Baum, M.S.; Schlische, R.W. Influence of preexisting fault fabric on inversion-related deformation: A case study of the inverted Fundy rift basin, southeastern Canada. Tectonics 2010, 29, 22. [CrossRef]

44. Brydon, J.E. Mineralogical analysis of the soils of the Maritime Provinces. Can. J. Soil Sci. 1958, 38, 157-162. [CrossRef]

45. Waldron, J.W.; Roselli, C.G.; Utting, J.; Johnston, S.K. Kennetcook thrust system: Late Paleozoic transpression near the southern margin of the Maritimes Basin, Nova Scotia. Can. J. Earth Sci. 2010, 47, 137-159. [CrossRef]

46. O'Reilly, G.A. Mafic and Felsic Intrusions in Carboniferous Rocks of Central Nova Scotia; Nova Scotia Department of Natural Re-sources: Baddeck, NS, Canada, 2005.

47. Hanor, J.S. Barite-celestine geochemistry and environments of formation. In Sulfate Minerals: Crystallography, Geochemistry, and Environmental Significance; Alpers, C.N., Jambor, J.L., Nordstrom, D.K., Eds.; Mineralogical Society of America: Chantilly, VA, USA, 2000; Volume 40, pp. 193-276. 